\title{
From Backwaters to Major Policymakers: Policy Polarization in the States, 1970- 2014
}

\author{
Jacob M. Grumbach
}

\begin{abstract}
Political scientists often characterize state and local governments as marginal and highly constrained in policymaking. However, I suggest that in recent decades state governments have moved from the margins to the center of partisan battles over the direction of U.S. public policy. Across 16 issue areas, I investigate interstate policy variation, policy differences across states, and policy polarization, the changing relationship between party control of state government and policy outcomes. Since the 1970s, interstate variation has increased such that an individual's tax burden, right to obtain an abortion, and other relationships to government are increasingly determined by her state of residence. Policy polarization increases dramatically after 2000 in 14 of the 16 areas. I show that party control increasingly predicts socioeconomic outcomes in the polarized area of health care, but not in the nonpolarized area of criminal justice.
\end{abstract}

n a 2011 phone call with a radio host impersonating David Koch, Wisconsin Governor Scott Walker explained that he was part of a national movement of conservative governors who "got elected to do something big" across their states. ${ }^{1}$ Democratic governors have similarly called for coordinated efforts by Democratic state governments to oppose initiatives by the Trump administration and Republican Congress. If their rhetoric is to be believed, politicians at the state level believe they are engaged in major struggles over the direction of public policy in the United States.

Despite the contentious rhetoric, political scientists have suggested that state governments are relatively marginal policymakers. Researchers have long seen the states as "the runt in the American governmental litter," with policy agendas that are highly constrained by economic realities and low legislative professionalism. ${ }^{3}$ Recent research largely continues this characterization.

\section{A list of permanent links to Supplementary Materials provided by the authors precedes the References section.}

*Data replication sets are available in Harvard Dataverse at: https://doi.org/10.7910/DVN/TZTW1J

Jacob M. Grumbach is a Doctoral Candidate at the University of California, Berkeley (jakegrumbach@berkeley. edu). He has previously published articles in Political Research Quarterly and Business \& Politics. His current research focuses on federalism, public policy, campaign finance, inequality, and the politics of race.
While some studies report important changes in state policy in the polarized era, ${ }^{4}$ the most comprehensive recent studies in this area conclude that state policy outcomes have been generally "stable" over the years, and that party control of government still plays only a "modest" role in policy differences between states. ${ }^{6}$

Yet there are reasons to expect that the role of states in American federalism has expanded since the 1970s. Although there are significant obstacles to electoral accountability in the states, ${ }^{7}$ mass polarization and residential sorting may increase the distance between the attitudes of voters across states. ${ }^{8}$ Well-resourced partisan interest groups have developed new strategies in coordination and lobbying that have led to significant policy changes in the states. ${ }^{9}$ Moreover, polarization and gridlock at the federal level both increases incentives for policy demander groups to venue shift to the states and limits the ability of Congress to create policy to preempt or standardize state laws. Indeed, journalists describe a strengthening relationship between an individual's state of residence and her legal right to obtain an abortion, own a firearm, join a labor union, or use drugs, as well as her tax burden, environmental regulatory regime, and generosity of the welfare state. ${ }^{10}$

Little research, however, has investigated shifts in the substance of state policy over time. ${ }^{11}$ I investigate here two dynamics in policy in the U.S. states: increased policy variation (the substantive differences between states) and policy polarization (the relationship between party control and policy outcomes). ${ }^{12}$ Importantly, I investigate the substance of policy change across 16 distinct issue areas such as abortion or tax policy. 
The analyses show a large increase in policy variation and a tightening relationship between party control and policy change in recent years. Across each issue area, the range of state policies has increased. For instance, the difference between the most restrictive states for abortion and the least restrictive states has expanded since Roe v. Wade (1973). This variation is increasingly related to party control of government; prior to 2000, whether a state was controlled by Democrats or Republicans said little about the policies it would adopt, but the parties have implemented highly divergent policy agendas after 2000 .

Issue area analysis shows two important areas of exception, however, where policy outcomes have not polarized: education and criminal justice. I corroborate this finding with analysis of its socioeconomic consequences. Health and welfare policy has sharply polarized in recent years, and I find that party control of state government increasingly predicts rates of health insurance coverage. However, in the non-polarized area of criminal justice, I find no change in the relationship between party control and incarceration rates.

The implications of this study suggest a growing need for research on American federalism in the age of hyperpolarization. Rather than a decentralized federalist system with vertical differences across levels and horizontal differences across regions, American governmental institutions look increasingly like a single arena of partisan combat over public policy.

\section{The Minimalist View of States}

Nearly three decades after Elazar predicted resurgent states in an emerging "neo-dualist" era of federalism, ${ }^{13}$ observers point to intensifying battles over public policy at the state level. However, there has been little empirical investigation of systemic policy changes in the states over time. Though scholars are now less likely to call them the "backwaters" of American politics, ${ }^{14}$ recent literature may only focus on the states as a means to increase one's $\mathrm{N}$ to 50 in order to "address a domain of questions with greater statistical rigor because of the large number of states." 15

Institutional, developmental, and historical research, in contrast, engages directly with temporal dynamics in federalism and public policy. ${ }^{16}$ Overwhelmingly, however, this research takes a minimalist view of state policymaking. John Kincaid, former director of the U.S. Advisory Commission on Intergovernmental Relations and a prominent scholar of federalism, describes a twentieth century in which the role of states shrank and U.S. federalism became "more adaptable to policy preferences defined increasingly by the national government" - where the federal government moved from "senior partner" to "commanding partner." ${ }^{17}$ By 1975, even the predominant federalism scholar William Riker suggested that the existence of lower levels of government "makes no particular difference for public policy." 18
Additional research lends credence to the minimalist view by highlighting the constraints that face lower levels of government in federalism. Fiscal federalism implies that the threat of exit from businesses and wealthy residents exerts downward pressure on taxation, redistribution, and regulation, ${ }^{19}$ which reduces the potential for variation across states. ${ }^{20}$ Fiscal federalism implies that state governments have little policy discretion compared to the federal government. They face a greater threat of exit, and with no ability to manipulate a floating currency, they face economic forces beyond their control and greater pressure to balance budgets. ${ }^{21}$

State legislators also lack the policymaking resources of members of Congress. ${ }^{22}$ Lower salaries increase the incentive to spend time earning money outside of their political offices, and fewer staff limits the ability to research and draft legislation. Even if state legislators face equivalent pressures from voters and interest groups as members of Congress, we would expect those in state capitals to be less productive due to these resource constraints.

Despite these constraints, however, roll-call voting in state legislatures has polarized in recent years. ${ }^{23}$ Whether the prior cause of polarization stems from voters, interest groups, or politicians themselves, greater polarization implies greater distance between the policy preferences of Democrats and Republicans, ${ }^{24}$ and thus increasing polarization of policy outcomes in the states. Yet the most comprehensive studies of state policy polarization over time, those of Caughey and Warshaw and Caughey, $\mathrm{Xu}$, and Warshaw, again conclude in favor of the minimalist view of state policy. While "Democrats and Republicans may disagree consistently and even violently," Caughey, $\mathrm{Xu}$, and Warshaw conclude that "the actual policy consequences of these disagreements are far less dramatic." 25 The increasingly partisan and ideologically consistent rhetoric of Democratic and Republican governors and state legislators is just that-talk, with little consequence for public policy. ${ }^{26}$

My empirical analysis challenges this line of research. I turn to measurement in a later section, but here I describe theoretical reasons that we might expect, contra the minimalist view, substantial policy polarization in the states.

\section{Polarized Federalism}

The minimalist view highlights the constraints on state policymaking and leads us to expect, at most, modest increases in state policy variation and polarization in recent years. But there are a number of theories that predict major changes in state policy-and major growth of state policy polarization. Popular explanations for congressional polarization, voters and interest groups may drive polarization in the states. There are also institutional reasons why polarization at the upper level of a federalist system can generate polarization at lower levels. This section briefly outlines these sets of theories. 
Theories of voters and public opinion. One set of explanations focuses on changes in the preferences of the median voter. Policy differences across states are likely to increase if the preferences of states' median voters are diverging. Some research finds evidence of polarizing ideological and policy attitudes in the mass public. ${ }^{27} \mathrm{An}$ additional plausible mechanism for diverging median voters is geographic sorting. Bishop argues that Americans have increasingly opted to live in communities that tend to share their political views. ${ }^{28}$

However, other research suggests that elected officials in the states are unlikely to be responsive to mass opinion. The electoral connection in the states may be weak because voters pay little attention to state politics, ${ }^{29}$ and the precipitous decline of state politics journalism may make policy even less "traceable" for voters. ${ }^{30}$ As a whole, there is little electoral accountability for state legislators who engage in behavior that is "out of step" with their constituents. ${ }^{31}$

Theories of interest groups. There are significant barriers to translating mass preferences into state policy, but more concentrated and well-resourced actors may be more influential. A second set of theories involves groups of intense policy demanders. A classic literature argued that concentrated and elite interests are advantaged at lower levels of government, ${ }^{32}$ which diffuse and mass interests can counter by "extending conflict" to higher levels. ${ }^{33}$ Relative to voters, who are often cross-pressured and inconsistent, ${ }^{34}$ concentrated interests and organized activist groups are likely to have intense and consistent preferences $^{35}$ - which, to the extent they are implemented, increase interstate policy variation.

Arguing that well-resourced organizational networks have increased their investments in state politics, recent studies harken back to this classic literature. Organizations' investments in lobbying and the provision of "model bills" to state legislators appear highly effective in shaping state policy outcomes. ${ }^{36}$ These organized investments in state politics may be especially influential because of groups' political advantages over voters. Voters are mostly immobile, but well-resourced organizations can make coordinated political investments across many states, and more strategically "venue shift" to favorable institutional arenas. ${ }^{37}$ Moreover, state legislators face considerable informational and human resource constraints relative to members of Congress, ${ }^{38}$ which potentially increases the effectiveness of groups' investments in informational lobbying. ${ }^{39}$

Not only do groups appear more involved in state politics generally, but the groups themselves are more partisan than a generation ago. Midcentury pluralists described groups that maintained running partnerships with both parties and party-group coalitions that reshuffled depending on the agenda item; ${ }^{40}$ antipluralists discussed "iron triangles" and other relationships in which powerful groups captured bipartisan committees and agencies in order to extract rents. ${ }^{41}$ Although some groups continue to partner with both major parties, contemporary research suggests that groups now tend to be much more aligned with a single party. ${ }^{42}$ The growing partisanship of the interest group environment may be especially extreme at the state level: Many of the groups that remain bipartisan are concentrated in the foreign policy and national security arenas, a policy area that is largely confined to national level.

Theories of institutional incentives. Research in "new institutionalism" and formal theory has shown that institutions structure and influence preferences and incentives, and that this is especially true of institutions associated with federalism. ${ }^{43}$ Specifically, it is plausible that polarization at the national level can generate polarization at lower levels of government in a federalist system.

This theory also gives a prominent role to policy demander groups. National level polarization may increase state policy polarization because federalism may serve as a "safety valve" for policy demanders who are stymied in Washington, and this safety valve grows more valuable as polarization increases. Polarization reduces the ability of the minority party and their aligned policy demanders to influence or extract compromises from the majority party, increasing the relative benefit of shifting their focus to the states. Frustrated climate activists may turn their hopes to the states, ${ }^{44}$ as might organized labor, ${ }^{45}$ LGBT rights activists, ${ }^{46}$ or antistatist and business interests. ${ }^{47}$

Polarization and divided government have produced gridlock and a slowdown of national policy production, ${ }^{48}$ again generating incentives for groups to venue shift to the states. ${ }^{49}$ Since the 1970 s, polarization has increased in Congress and divided federal government has become a more frequent occurrence. ${ }^{50}$

This has led to policy gridlock ${ }^{51}$ and "drift" higher costs of national policy change for policy demanders. Faced with federal gridlock, policy demanders may increasingly turn to states to implement their agendas. Federal gridlock also means that these policy demanding groups can be more confident than in earlier periods that their state policy victories will not soon be reversed by federal legislation or court rulings. ${ }^{53}$

In the rarer moments when important federal policy does pass, polarization and divided government may increase incentives for members of Congress to delegate authority to the states. ${ }^{54}$ A legislator who would ideally implement his or her ideal policy across all 50 states may accept a decentralized policy as a second-best option if it moves the average outcome (such as the policy regime for the average state or average individual) toward his or her ideal. Moreover, the district-based electoral connection in Congress can improve the relative appeal of the secondbest option because "representatives know that when they 
delegate to state and local agents, policy for their constituents will be set by representatives elected by those same constituents." 55 Indeed, the rise of polarization in Congress has coincided with what scholars call a "devolution revolution." ${ }^{56}$ In a similar fashion, the federal judiciary has undergone a "federalism revolution" in which the courts are an increasingly "state friendly arena" 57 precisely during an era of increasingly partisan and narrow (5-4 split) decisions. ${ }^{58}$

\section{Measuring Policy Outcomes}

There are strong reasons to expect increased policy variation and polarization in the states, but to what extent does it occur in recent decades? Do policy outcomes diverge over time, and is this divergence related to party control of government? In this section, I describe my strategy to measure policy outcomes and estimate the changing relationship between party control and policy.

This study employs the most comprehensive dataset of state policy outcomes since $1970 .{ }^{59}$ To build it, I collect data on 35 policies, to which I add data from Jordan and Grossmann, Caughey and Warshaw, and Boehmke and Skinner to create a dataset of 135 policies. ${ }^{60}$ (I also extend years of coverage for 16 policies from the other datasets.) Caughey and Warshaw provide a detailed description of many of the policies, which can be binary (e.g., Right to Work laws), ordinal (e.g., mandatory parental notification or consent for a minor's abortion), or continuous (e.g., marginal tax rate on high incomes). ${ }^{61}$ Table 1 lists the policies, and I provide descriptions and sources for each policy in the online appendix.

The data I collect covers policies of considerable importance. They include voter ID laws, state capital gains taxes, as well as various regulations related to public sector unions, abortion rights and coverage, campaign finance, and immigrant workers. ${ }^{62}$ Of particular note is my data collection of criminal justice policies. Although some research focuses specifically on dynamics in criminal justice policy, ${ }^{63}$ research that summarizes policy across issue areas has largely neglected incarceration. ${ }^{64} \mathrm{I}$ collect data on laws that criminal justice research considers central to the rise of mass incarceration: truth-in-sentencing laws, which require individuals to serve a minimum percentage of their original sentence; three strikes laws, which increase penalties for an individual's third felony; and determinate sentencing laws, which specify mandatory minimum sentences. $^{65}$

To measure party control of government, I use variables that indicate whether a state is under unified Democratic control, unified Republican control, or divided control. ${ }^{66}$ While control of the executive branch or one or more legislative chamber may have an independent or partial effect on policy outcomes, ${ }^{67}$ the polarized federalism theory focuses on unified control because polarization and divided government interact to produce gridlock. ${ }^{68}$ I provide additional models with measures of control of the governorship, lower house, and upper house in the online appendix.

Key to the analyses is the comparison of the partypolicy relationship across time. Because policy change is rare compared to other political dynamics, estimating a completely dynamic party effect (i.e., by year) is difficult. Precision and clarity are greatly improved by estimating an average party effect for different eras that span multiple years. ${ }^{69}$ I compare the association between party control and policy change during two eras: the 1970-1999 period and the 2000-2014 period. $^{70}$ In practice, this entails interacting the party control variable with a dummy variable for the 2000-2014 period to estimate the marginal effect of party control on policy change during the different eras.

\section{Unidimensional Measures}

Political scientists often summarize public opinion, legislative votes, and more recently, policy outcomes on a unidimensional left-right dimension. Recent unidimensional policy measures provide a summary of the ideological content of policy on a dimension typically described as "policy liberalism" or "the role of government."

As a first cut at the data, I estimate policy variation and polarization with four unidimensional left-right measures of policy outcomes. The first is the State Policy Liberalism (SPL) measure from Caughey and Warshaw (2016), a set of state-year policy ideal points generated from a dynamic Bayesian IRT model. Second, I estimate the same ideal point model with my expanded policy dataset to produce an Expanded SPL measure. The third and fourth measures are Substantive Scales, simple additive indices (averages) that are the sum of a state's liberal policies minus its conservative policies in a given year. These measures serve as expert-coded alternatives to the Bayesian IRT latent dimension estimates and are analogous to the "Policy" measure from Erikson, MacKuen, and Stimson. ${ }^{72}$ One of the additive indices weights policies equally, while the other is the average of issue area-specific indices. (Subsequent sections address how the ideological direction of policies is determined.) All measures are normalized to a range between 0 and 1 .

I calculate two measures of policy variation with these unidimensional scales: the range and the standard deviation of policy ideal points across states in each year. I plot yearly estimates from 1970 to 2014 in appendix figure 5 . The spread of ideal points widens greatly since the 1970s. The range and standard deviation estimates are remarkably similar across the measures. The range of ideal points is at least a third larger in the 2010s than in the 1970s and 80s, and the standard deviation is at least two-thirds larger. ${ }^{73}$

These measures suggest that policy polarization has similarly increased. Using dynamic panel regressions, 


\section{Table 1}

\section{State policies (1970-2014)}

\section{Abortion}

Abortion insurance restriction

Abortion legal

Consent post-Casey

Consent pre-Casey

Emergency contraception

Gestation limit

Medicaid covers abortion

Parental notice

Partial birth abortion ban

Physician required

Waiting period

Campaign Finance

Corporate contribution ban

Dollar limit on individual contributions

Dollar limit on PAC contributions

Limit on individual contributions

Limit on PAC contributions

Public funding elections

Civil Rights/Liberties

Bible allowed in public schools

Corporal punishment ban

Discrimination ban public accommodations

ERA ratification

Fair employment comm.

Gender discrimination ban

Gender equal pay law

Moment of silence in public school

No fault divorce

Physician-assisted suicide

Public breast feeding

Religious Freedom Rights Amendment

Reporters right to source confidentiality

State ADA

State ERA

Criminal Justice

Death penalty repeal

Determinate sentencing

\section{DNA motions}

Three strikes

Truth-in-Sentencing

Education

Charter school law

Higher ed. spending

K-12 spending

School choice

Environment

Bottle bill

CA car emissions

Endangered species

E-waste

GHG cap

Renewables fund

Solar tax credit

State NEPA

Gun Control

Assault weapon ban

Background checks (dealers)

Background checks (private)

Brady law

Dealer licenses required

Gun registration

Open carry

Sat. Night Special ban

Stand Your Ground

Health and Welfare

ACA exchange

AFDC payment level

AFDC Up

CHIP eligibility (children)

CHIP eligibility (infants)

CHIP eligibility (pregnant women)

Expanded dependent coverage

Medicaid adoption

Medicaid expansion

Pre-BBA CHIP eligibility
Senior prescription drugs

TANF eligibility

TANF payment level

Welfare drug test

Welfare time limit

\section{Housing/Transportation}

Growth management

Lemon law

Rent control ban

Tort limit

Immigration

Drivers licenses for undocumented

English official language

E-verify

E-verify ban

In-state tuition for undocumented

State cash benefits for recent immigrants

State food benefits for recent immigrants

State health benefits for recent immigrants

Labor (Private Sector)

Disability insurance

Local minimum wage ban

Local sick leave law ban

Minimum wage

Paid family leave

Paid sick leave

Prevailing wage

Right to work

Unemployment comp.

Labor (Public Sector)

Ban on agency fees (state)

Collective bargaining (firefighters)

Collective bargaining (local)

Collective bargaining (police)

Collective bargaining (state)

Collective bargaining (teachers)

LGBT Rights

Civil unions and marriage
Gay marriage ban

Hate crime law

LGB discrimination ban public accommodations

(GB employment discrimination ban

Sodomy ban

Marijuana

Marijuana decriminalization

Medical marijuana

Taxes

Corporate tax rate

EITC

Estate tax

ncome tax

Sales tax

Tax burden

Top capital gains rate

op income rate

Voting

sentee voting

Early voting

Motor voter

Voter ID

Other

Animal cruelty felony

Beer keg registration

Bike helmet required

Casinos

Cigarette tax

Drinking age 21

Grandparent visitation

Living wills

ottery

Mandatory car insurance

Mandatory seatbelts

Motorcycle helmet required

Smoking ban (restaurants)

Smoking ban (workplaces)

Zero tolerance underage drinking

Note: Issue area categories in bold. 
appendix figure 6 plots the marginal effect of unified party control of government on change in ideal points for the 1970-1999 period and the 2000-2014 period. All of the estimates show at least a twofold increase in the magnitude of the relationship between party control and policy ideal points. ${ }^{74}$

The expanding variation and polarization evident in the unidimensional analysis motivates the investigation of issue-specific policy dynamics. Unidimensional ideal points serve as strong summary measures, but generally, they may create obstacles to inference by obscuring multidimensional variation or conflating extremism and consistency, ${ }^{75}$ and they rely on relatively strong assumptions about the comparability of policies across issue domains. More importantly, it is difficult to draw conclusions about the substantive content of policy-its effect on members of the polity-from unidimensional ideal point estimates. Policy scholars may be interested in more specific temporal dynamics in residents' relationship to government. Are state abortion laws more or less restrictive? In which direction have state tax rates, restrictions on campaign contributions, and the generosity of welfare benefits moved in recent decades?

Additionally, although they may be advantageous in the study of roll-call votes, ${ }^{76}$ there are two reasons to prefer straightforward additive indices over latent dimension estimates (e.g., factor analysis or Bayesian IRT) for the measurement of policy outcomes. First, historical, normative, and policy scholarship provides clear priors about the ideological content of policy. Empirically deriving model parameters (the ideological content of policy) from the data rests on the joint assumption that (a) liberal states are liberal because they pass liberal policies, and (b) that liberal policies are liberal because liberal states pass them. When this assumption is violated historically (e.g., during the 1960s and 1970s conservative Southern states were early adopters of liberal abortion laws), the model may produce parameters that do not conform to substantive understandings about the ideological content of policy. In a separate analysis, I find that parameters for some relatively inconsequential policies (e.g., mandatory registration of beer keg rentals) are larger than those of more important policies, and that some similar laws have parameters that point in opposite directions. ${ }^{77}$ Second, the real world consequences of substantive policy is, for the most part, additive. Whereas latent dimension estimates rely on the correlations between policy items to provide "relative" measures of policy outcomes, ${ }^{78}$ averages can provide absolute measures of policy outcomes.

\section{Policy Indices by Issue Area}

Issue area measures provide a clearer picture of historical changes in policy substance. Although many studies have employed summary measures of policy outcomes in a single issue area, ${ }^{79}$ mine is the first to compare across many issue area indices. I group the policies into 16 discrete issue areas: abortion, campaign finance, civil rights and liberties, criminal justice, drug policy, education, environment, gun control, health and welfare, housing and transportation, immigration, labor (private sector), labor (public sector), LGBT rights, taxes, and voting.

In each area, I calculate a simple substantive measure of average policy outcomes: the number of liberal policies minus the number of conservative policies. ${ }^{80}$ Because policies can be binary (e.g., medical marijuana laws), ordinal (e.g., voter ID laws, which can be strict or nonstrict), or continuous (e.g., minimum wage level), I normalize each policy to range from 0 to 1 . A binary policy, which a state either has or does not have, takes on the values of 0 or 1 , whereas an ordinal or continuous policy, such as a tax or minimum wage, is transformed to the $[0,1]$ scale. A state's score in an issue area index is therefore the sum of the liberal policies minus the sum of the conservative policies.

This kind of measure relies on three assumptions: first, the ideological "direction" of policy (whether it is liberal, conservative, or neither); second, that policies are of equal substantive importance; and third, that the direction and importance remain constant over time. These assumptions are unlikely to be satisfied in practice, especially equality of substantive importance. ${ }^{81}$ However, I argue that these simple index measures strike a balance between agnosticism, precision, transparency, risk of bias, and substantive interpretability.

Determining the ideological direction of more than 130 policies is a difficult task. The primary left-right ideological dimension, or "what goes with what" has changed over time, but for the most part political observers characterize policies on the left to be those that 1) expand the use of state power for economic regulation and redistribution, ${ }^{82}$ or to increase or protect the rights of historically marginalized groups in society (black Americans and other nonwhite racial groups, women, LGBT individuals, immigrants, and religious minorities); ${ }^{83}$ and 2) restrict the use of state power for the punishment of deviant social behavior. ${ }^{84}$ Policies on the right do the opposite. $^{85}$ Although there is considerable nuance throughout political and intellectual history, in short, left policies promote social libertarianism and economic interventionism, while right policies promote traditional (incumbent) social values and oppose state intervention in markets.

Yet even with this large body of historical and normative scholarship, there is still no objective, unifying test of whether a certain moral principle, political action, or legal statute is on the left or right. Many scholars argue that the first dimension of politics represents the "size of government," ${ }^{86}$ but this is not always the case. For instance, policies that expand rights and protections for black Americans, which are understood to be liberal, can 
involve expansions of state power (e.g., anti-lynching laws) or restrictions on state power (e.g., laws that reduce prison sentences). The same is true of abortion laws, where Medicaid coverage of abortion and bans on "partial birth abortion" both involve greater state intervention, but are quite ideologically distinct. It is thus no surprise that there is an ongoing debate about whether the clustering of policies along partisan and ideological lines is due to "natural" ideological or psychological principles, ${ }^{87}$ or whether they are the products of idiosyncratic historical coalition partnerships between interests in society that over time became path-dependent. ${ }^{88}$

I argue that an issue-specific left-right conceptualization can improve inference for studies of policy dynamics. Rather than assuming that issues "go together" in unidimensional space, table 2 shows conceptual dimensions that determine the ideological direction of policies within each issue area. ${ }^{89}$ The left-right dimension for abortion policy, for example, represents the legality and costs (broadly defined) of obtaining an abortion. Other issue areas represent multiple related concepts. Tax policy, for example, is comprised of two concepts: absolute rates and progressivity (the distribution of marginal rates across income levels), and health and welfare policy is comprised of both benefit levels and the strictness of eligibility. I base a policy's directionleft, right, or, in a small number of cases, neither-on its expected effect on the issue-specific dimension. This issuespecific conceptualization also helps to avoid the problem of sorting and shifts over time regarding which issues "go together" on a single left-right dimension. While the cluster of issues on the left and right has shifted over the nineteenth and twentieth centuries, ${ }^{90}$ issue-specific assessments (e.g., whether a policy restricts or broadens access to abortion) have largely remained constant. ${ }^{91}$

\section{Interstate Policy Variation}

In this section I estimate change in state policy since 1970. Figure 1 plots each issue area policy index. The grey lines represent the policy outcomes for each individual state over time.

States' policy outcomes within each issue area (the grey lines) diverge greatly over time; this represents increased overall variation in state policy outcomes in each area. Compared to the 1970s, the policy regime under which an individual lives is increasingly determined by her state of residence. For instance:

- Abortion: In 1973, states only differed in Medicaid coverage for abortion and other minor regulations. By 2014, the most restrictive states mandate waiting periods, parental notification, counseling, licensed physicians, a 20-week gestation limit, and restricted insurance coverage for abortion.

- Environment: In 1970, the greenest states had state EPAs and endangered-species laws. By 2014, they had strict regulations of greenhouse gas emissions for cars and utilities, solar tax credits, and a plethora of recycling programs.

- Gun Control: In 1970, the least strict states allowed open carry and the strictest states required dealer licenses and purchaser background checks. By 2014, the least strict states had added Stand Your Ground

\section{Table 2}

Ideological content of policy issue areas

\begin{tabular}{|c|c|}
\hline Issue Area & Concept \\
\hline Abortion & $\begin{array}{l}\text { Legal right to and cost of emergency contraception and } \\
\text { abortion }\end{array}$ \\
\hline Campaign finance & $\begin{array}{l}\text { Restrictions on individual, corporate, PAC contributions; } \\
\text { public funding of elections }\end{array}$ \\
\hline Civil rights \& liberties & $\begin{array}{l}\text { Penalties for discrimination based on race, gender; religious } \\
\text { privileges }\end{array}$ \\
\hline Criminal justice & Punitiveness \\
\hline Drugs & State legality of federally illicit drugs (especially marijuana) \\
\hline Education & Spending; public vs. private control \\
\hline Environment & Restriction on emissions, chemicals; protection of species \\
\hline Guns & Legal rights to purchase, own, or carry a firearm \\
\hline Health \& welfare & Generosity (eligibility, benefit levels) \\
\hline Housing \& transportation & Command and control \\
\hline Immigration & $\begin{array}{l}\text { Legal right to public services for undocumented; regulation of } \\
\text { hiring undocumented }\end{array}$ \\
\hline Labor & Right to unionize; wage laws \\
\hline LGBT & Protections or penalties for homosexuality \\
\hline Taxes & Marginal rate; progressivity \\
\hline Voting & Cost, access to voting \\
\hline
\end{tabular}


laws, while the strictest states banned assault weapons and mandated registration and waiting periods for purchases.

- Health and Welfare: In 1970,states varied in AFDC benefits and Medicaid adoption. By 2014, Massachusetts offered generous Temporary Assistance for Needy Families (TANF) and SCHIP benefits and had expanded Medicaid, while Alabama did not expand Medicaid, requires drug tests for public benefits, and requires a monthly income below $\$ 268$ for a family of three to qualify for TANF. ${ }^{92}$

- Immigration: In 1970, states mostly varied in laws establishing English as official state language, and all legal immigrants were eligible for public welfare and health programs. By 2014, only some states provide public benefits to new legal immigrants. ${ }^{93}$ Some states provided in-state tuition for undocumented college students, driver's licenses for undocumented immigrants, and banned the use of e-verify for employment, while other states require all employers to use it.

- Taxes: In 1970, some states had no income or capital gains taxes, while the highest tax state, Vermont, had a $5.54 \%$ top capital gains rate and $14.88 \%$ top income rate. By 2014, many states continued to collect no income or investment taxes, but California had a $14.1 \%$ top capital gains rate and a $14.1 \%$ top income rate.

Some areas, such as environmental policy, become more liberal over time on average. All of the major policies in this area increase environmental regulation or public spending in pursuit of environmental quality, and the most conservative states on the environment simply do not pass the major environmental laws that the "green" states do. Abortion policy, in contrast, tracks more conservatively since Roe $v$. Wade (1973). A few states become more liberal on abortion over time as they pass laws to provide Medicaid coverage for abortion and over-the-counter emergency contraception. This liberal trend, however, is swamped by the spread of abortion restrictions in states, such as mandatory parental notice for minors and bans on "partial birth abortion." Though not included in this analysis, prior research finds similar dynamics for Targeted Regulation of Abortion Provider (TRAP) laws, which "single out abortion providers and impose on them requirements and regulations that are excessive and more stringent than those imposed on other medical practitioners." ${ }^{\prime 4} \mathrm{~A}$ third set of issue areas, such as immigration and labor, sees similar growth in variation, but does not become more liberal or conservative on average since the 1970s.

Each issue area shows growing policy variation across states, but they also show partisan policy polarization: Policy outcomes in Republican states are more distant from those in Democratic states. In particular, figure 1 shows the correlation between party control and policy outcomes in each area (with the blue lines representing unified Democratic states, the red lines representing unified Republican states, and the green line representing divided states). There are two issue areas that do not fit this pattern, where increased overall variation appears nonpartisan: criminal justice and education. The averages of Republican, Democratic, and divided states in figure 1, however, are simple correlations, so the growing policy divergence by party control could be simple sorting - states with conservative policies becoming Republican and states with liberal policies becoming Democratic. To test the changing relationship between party control and policy change, in contrast, I estimate dynamic panel regressions and compare the marginal effect of party control on policy outcomes for the 1970-1999 period and the 2000-2014 period. Figure 2 plots these results.

\section{Partisan Policy Polarization}

Figure 2, which tests the relationship between party control and policy change, corroborates the correlations shown in figure $1 .{ }^{95}$ Again, in 14 of the 16 issue areas, the party effect polarizes after 1999: There is a greater difference in the effect of unified Democratic control relative to that of unified Republican control in the 2000-2014 period than in the 1970-1999 period. The amount of polarization depends on the partisanship of policy - that is, whether, for instance, Democratic states increase taxes relative to Republican states. But the overall amount of policy activity in a given area matters. For example, states become less active on civil rights and liberties as time progresses, but more active in areas like drug policy, LGBT rights, and voting rights (refer to figure 9 in the online appendix for counts of policy changes).

Figure 2 shows that party control is no better at predicting policy change in criminal justice or education in recent years. Both before and after 2000, party control does not predict change in criminal justice policies. States controlled by Democrats pass punitive and liberal criminal justice policies at similar rates to divided and Republican states. In both eras, states controlled by Democrats are slightly more likely to pass liberal education policies (e.g., increase spending in K-12 or higher education) and less likely to pass school choice, voucher, and charter laws. However, party control becomes slightly less predictive of education policy changes after 2000. In both of these issue areas, the static or decreasing predictiveness of party control stands in contrast to the other 14 issue areas in which party control increasingly explains policy change.

But does this policy polarization matter for the lives of these states' residents? Does it matter for socioeconomic outcomes that there is polarization in 14 issue areas, such as tax and health policy, but non-polarization in criminal justice and education? In the next section I provide evidence that it does. In the polarized area of health policy, party control of state government increasingly predicts rates of 


\section{Figure 1}

\section{Issue area scales by party}

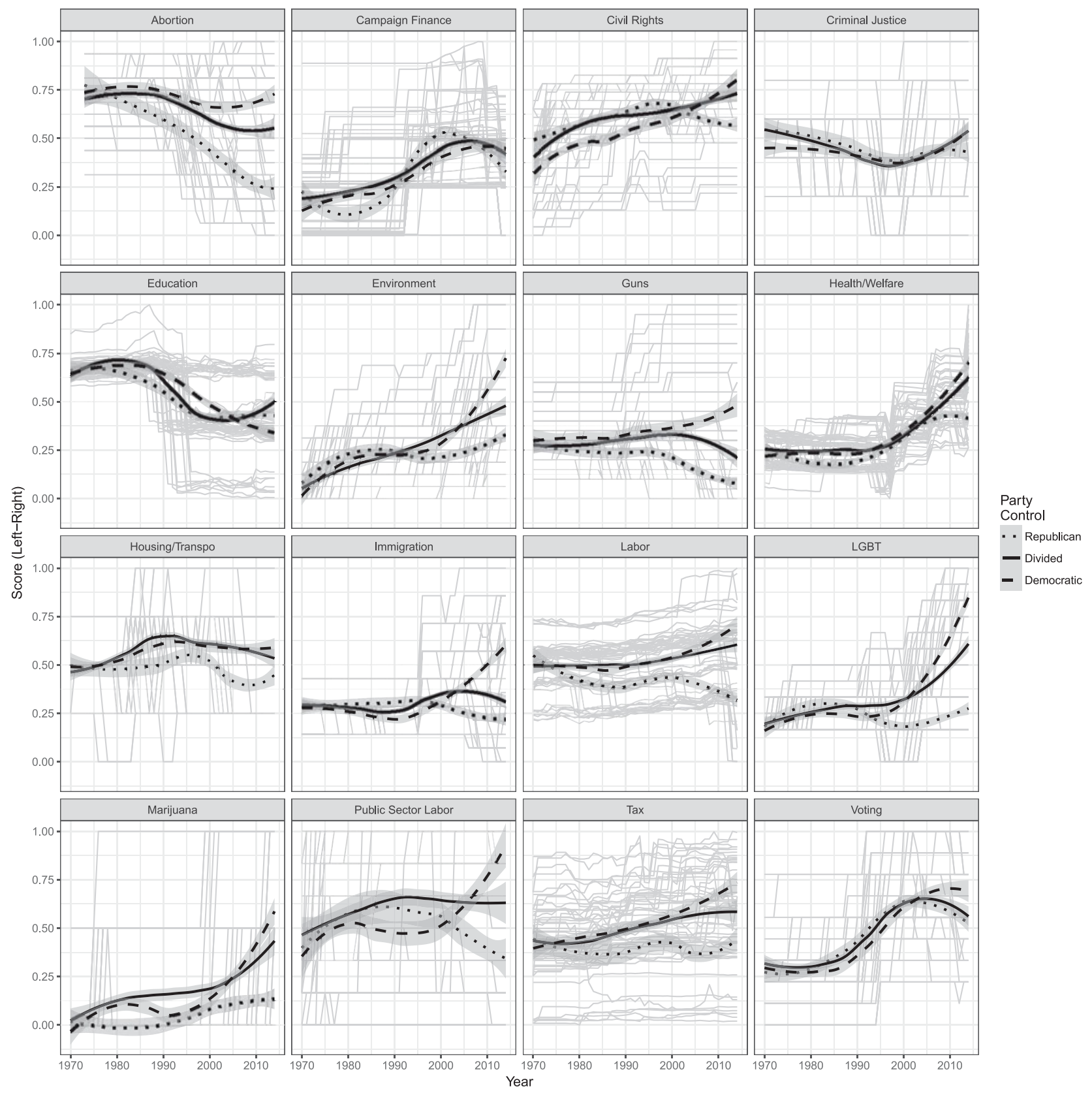

health coverage. In the non-polarized area of criminal justice, however, party control does not increasingly predict rates of incarceration (overall or among black residents).

\section{The Socioeconomic Consequences of Policy Polarization}

The polarization of policy carries major socioeconomic consequences for residents. In the polarized areas of health and environmental policy, party control of state government increasingly predicts rates of health coverage and carbon intensity of a state's energy supply, respectively. In the non-polarized areas of criminal justice and education, however, party control does not increasingly predict rates of incarceration (overall or among black residents) or graduation rates, respectively. In this section, I focus in depth on health and criminal justice policy. 
Figure 2

Party effect on issue area scales

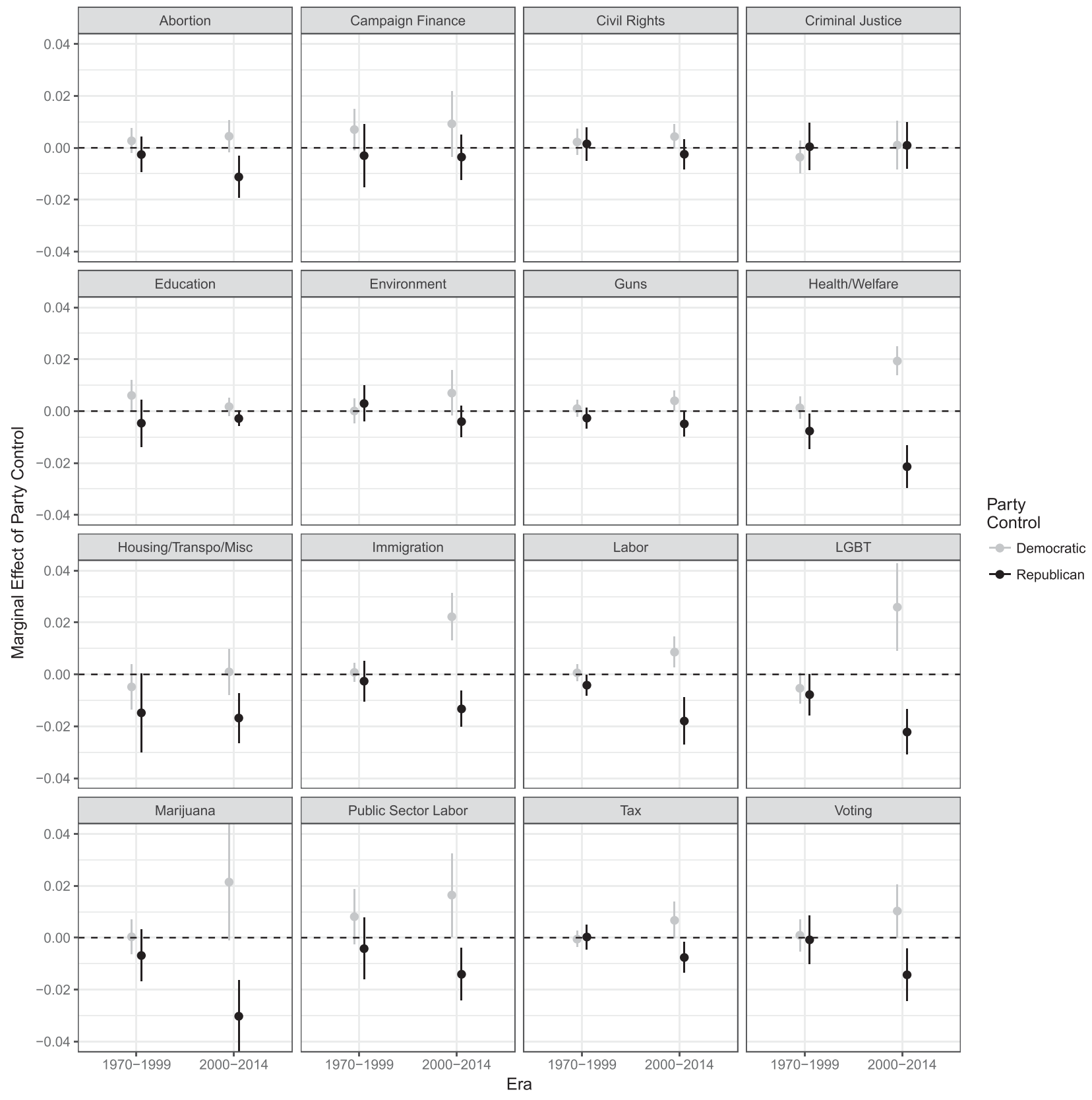

Analysis of socioeconomic outcomes in education and environmental policy is provided in the online appendix.

The health policy agendas of the national Democratic and Republican parties have been distinct since at least the 1930s. Health policy in the states has been similarly polarized for decades, as Democratic states tended to have more generous Medicaid eligibility and benefits. As the role of states in health policy expanded with the development of state prescription drug benefits for seniors, as well as federal grants for the State Children's Health Program (1998) and Medicaid expansion under the Affordable Care Act (2014), state health policies increasingly varied-and this variation was increasingly related to party control of government.

Socioeconomic outcomes related to health policy polarized accordingly. Figure 3 shows the relationship 


\section{Figure 3 \\ Party control and health insurance coverage \\ A. Correlation \\ B. Marginal effect of party control}

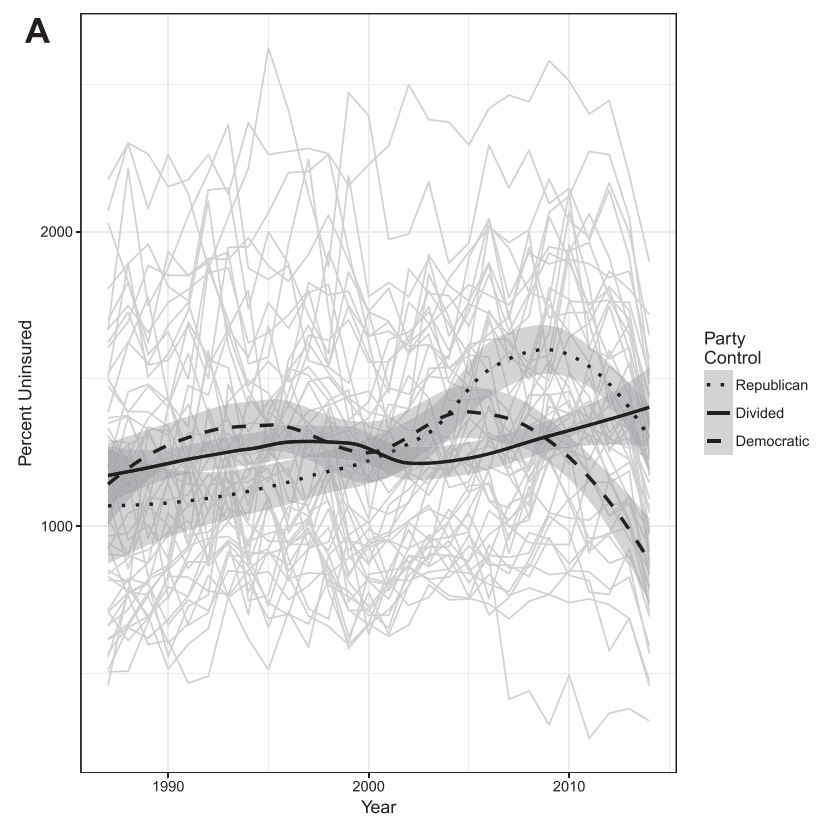

between party control and the uninsured rate. Plot A displays state uninsured rates (the grey lines) and the average Republican (red), Democratic (blue), and divided (green) state from 1987 through 2014. Plot B shows the marginal effect of party control for the 1987-1999 and 2000-2014 periods from different time-series regression models.

In both the correlation and the regressions, party control of government is increasingly associated with health insurance coverage in more recent years. Whereas prior to 2000, party control does not predict change in the uninsured rate, after 2000 unified Republican control is associated with a 0.75 percentage-point increase in the uninsured rate and unified Democratic control is associated with a 0.75 percentage-point decrease in the uninsured rate. These differences in coverage are of considerable social consequence. Health policy scholars, for instance, "estimate the number of deaths attributable to the lack of Medicaid expansion in opt-out states at between 7,115 and 17,104." 96

In contrast, education and criminal justice policies are - uniquely — non-polarized. In education, Democratic state governments pass school choice and charter school laws, and spend at similar rates to Republican state governments. ${ }^{97}$ In criminal justice, Democratic and Republican states both instituted "tough on crime" laws

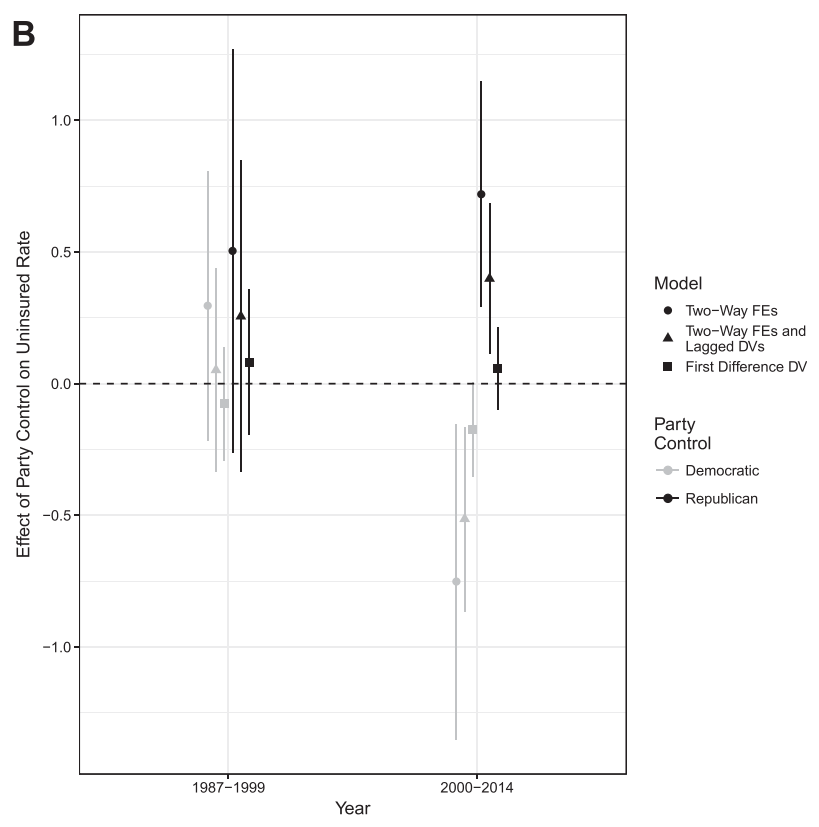

that led to mass incarceration. The lack of polarization in these areas relative to others has largely reflected the positions of the national Democratic and Republican parties, and a substantial literature describes the bipartisan history of policymaking in these areas. ${ }^{98}$

Mass incarceration - the internationally unprecedented number and proportion of Americans, disproportionately black, under correctional control-has drawn increasing scholarly attention with respect to its origins ${ }^{99}$ and consequences. ${ }^{100}$ Mass incarceration is in large part the result of changes in law and bureaucracy in the U.S. states. Of the powers reserved to the states in the 10th Amendment of the U.S. Constitution, police powers are the most prominent and likely the most socially consequential. State and local agencies account for the overwhelming majority of law enforcement, and the federal prison system houses less than six percent of the U.S. incarcerated population. There is new but limited research focusing on the interaction of mass incarceration and federalism. ${ }^{101}$

Despite the social importance and comparative punitiveness of American criminal justice policy, its politics has been mostly bipartisan as the parties compete to be perceived as "tough on crime." Weaver discusses how after 1968 "even liberal Democrats did not talk about civil rights without deploring crime." ${ }^{102}$ Alexander places responsibility on not only the Republican Party, but also 
on Democrats, for adopting "tough on crime" policies, especially during the 1990s. ${ }^{103}$ As shown in table 3, punitive criminal justice policy has not polarized in the states. An exception is the repeal of the death penalty; five Democratic states repealed the death penalty between 2000 and 2014 . $^{104}$

Yates and Fording find a significant association between Republican control of government and incarceration rates for white and especially for black people between 1978 and $1995,{ }^{105}$ and I similarly find a statistically significant effect of unified Republican government for the 1978-1999 period. $^{106}$ The substantive effect, however, is modest and inconsistent across models: The two-way fixed-effect model (the least strict test) shows an increased incarceration rate of about 30 people per 100,000 residents, but the other models show no effect (refer to Plot B in figure 4). An increase in a state incarceration rate of 30 individuals per 100,000 residents is substantively minuscule in a society in which one in 36 adults is under correctional jurisdiction. ${ }^{107}$

More importantly, there is no evidence of a polarization of incarceration rates by party across time. This decreased

\section{Table 3}

\section{Criminal justice policies by party control}

\begin{tabular}{|c|c|c|c|c|c|c|}
\hline & \multicolumn{6}{|c|}{ Policies Passed (Repealed) by Party Control } \\
\hline & \multicolumn{2}{|c|}{ Democratic } & \multicolumn{2}{|c|}{ Divided } & \multicolumn{2}{|c|}{ Republican } \\
\hline & 1970-1999 & 2000-2014 & 1970-1999 & 2000-2014 & 1970-1999 & 2000-2014 \\
\hline Three strikes & 8 & 1 & 11 & 1 & 5 & 0 \\
\hline Determinant sentencing & $6(1)$ & 1 & $11(1)$ & 0 & 2 & $0(2)$ \\
\hline Truth in sentencing & 5 & 0 & $4(2)$ & 0 & 1 & 0 \\
\hline Death penalty repeal & 2 & 5 & 1 & 1 & 0 & 0 \\
\hline
\end{tabular}

Note: Democratic and divided state governments passed more punitive criminal justice policies than did Republican governments, though removals of the death penalty mostly occurred in Democratic states. Numbers in parentheses represent repeals.

\section{Figure 4}

\section{Party control and incarceration}

\section{A. Correlation \\ B. Marginal effect of party control}
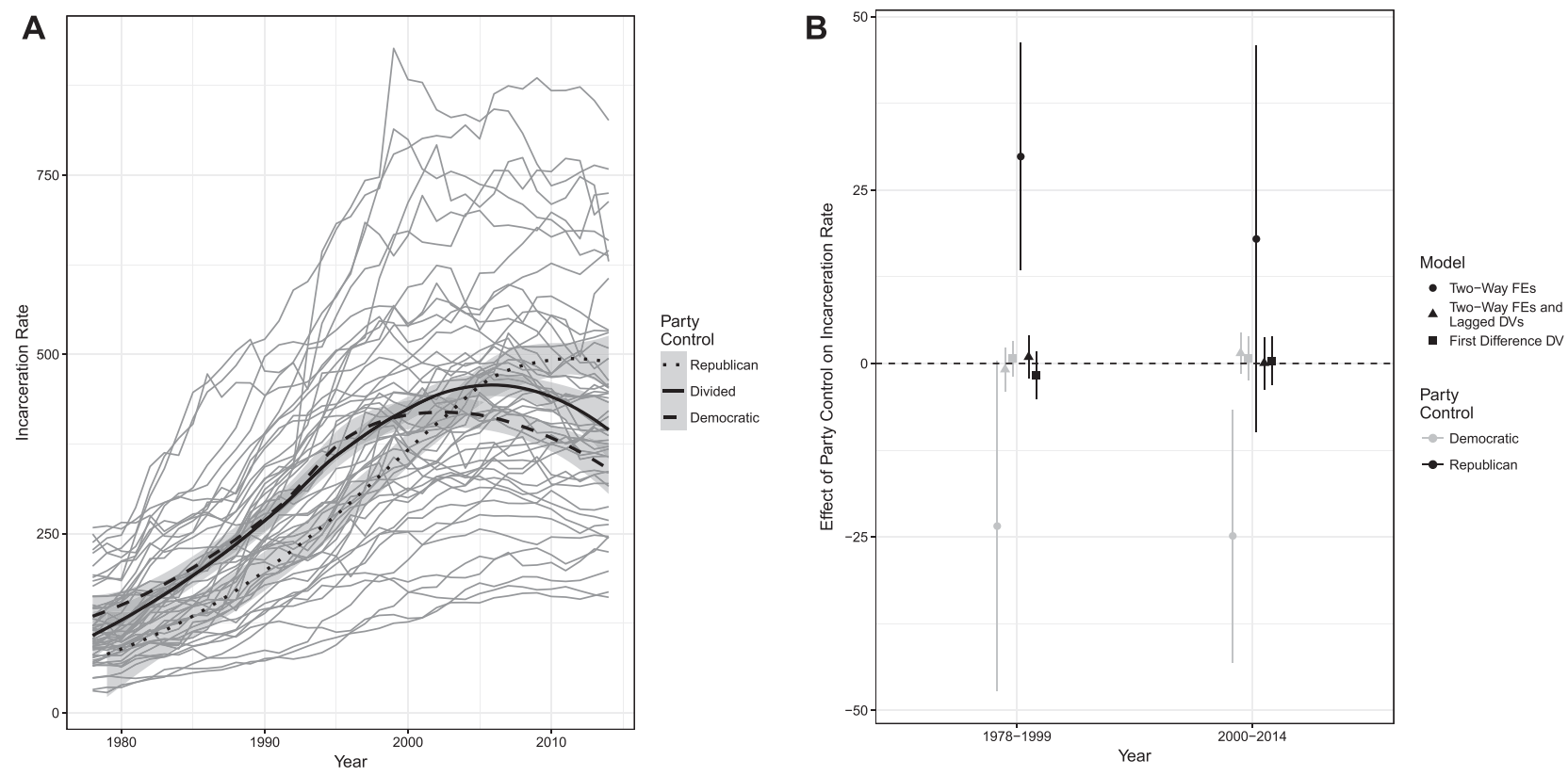
effect of Republican control in the post- 2000 period is a stark contrast to the rapid polarization in other policy areas.

I also provide estimates of the relationship between party control and the incarceration rate for black people in the online appendix, figure 10. Even more than for the overall incarceration rate, the black incarceration rate becomes less polarized after 2000. For most models prior to 2000, Republican control is associated with an increase in the black incarceration rate of about 100 per 100,000 residents, but the party differences decrease after 2000 .

Overall and black incarceration rates do not appear to polarize in the states, but recent years have seen growing partisan conflict over the use of private prisons. ${ }^{108}$ The use of private prisons may be more polarized than overall incarceration because it may generate conflict not only over crime and punishment concerns, but also over profit incentives for punitiveness, reports of inhumane conditions, and the fundamental role of the state and the social contract. ${ }^{109}$ I estimate the relationship between party control and the percent of inmates who are housed in privately owned facilities in the online appendix, figure 11, but only beginning in 1999 due to a lack of available data. Analogous bivariate and panel regression analyses suggest a modest relationship between party control and private prisons. After 2010, Democratic states have significantly lower proportions of inmates in private facilities. However, the panel regressions show at most a small effect of party control (less than 1\%), which is only statistically significant in the model employing the first differenced dependent variable (not the two-way fixed effects or lagged models).

Health policy and criminal justice are substantively important and illustrative cases in which major socioeconomic outcomes are polarized to the extent that relevant policies are polarized. This pattern generalizes further. Like diverging tax rates, state governmental revenue and spending have polarized over time, with Democratic control predicting greater increases relative to Republican and divided states in recent years. In the polarized environmental policy area, carbon efficiency is also predicted by party control of government (refer to the online appendix, figure 12). In contrast, non-polarized policy in the issue area of education, like criminal justice, appears to be associated with non-polarized socioeconomic outcomes: Party control does not predict high school graduation rates any more in recent years than it does in earlier years (refer to the online appendix, figure 13), ${ }^{110}$ and it barely predicts charter school enrollment (refer to the online appendix, figure 14).

\section{State Resurgence}

There are strong historical and theoretical reasons to expect state governments to be marginal players in American policymaking. Compared to the federal government, states face greater threat of exit from business and wealthy residents. Their legislatures are poorer in terms of the time, money, and information required to change policy. Major interstate differences in policy, such as the legality of racial segregation or gender discrimination in employment, have been washed away by landmark federal policies. Yet this minimalist characterization of states has grown antiquated.

While the federal government grew more gridlocked, states implemented major policies that shape the lives of their residents. Federal laws from the 1930s through 1970s decreased interstate variation in many issue areas. ${ }^{111}$ Since 1970, in contrast, interstate variation increased as some states implemented restrictions on guns, abortion, labor unions, welfare, and voter eligibility, while others loosened restrictions. Moreover, some of the most significant recent federal policies have served to increase interstate variation rather than decrease it. In addition to welfare devolution in 1996, ${ }^{112}$ the Supreme Court ruling in NFIB v. Sebelius (2012) gave states great discretion in the implementation of the Affordable Care Act, the choice of whether to expand Medicaid and create a state-run health insurance marketplace. ${ }^{113}$

There are notable exceptions where Congress and the federal courts have decreased variation in state law, however. In a famous example of "coercive federalism," the National Minimum Legal Drinking Act of 1984 threatened to withhold federal highway grants from states that did not increase their drinking age to 21 . The area of LBGT rights is also prominent. Lawrence v. Texas (2003) invalidated state sodomy bans. Though not included here because it occurred after 2014, the Obergefell $v$. Hodges (2015) case legalized same-sex marriage by invalidating state marriage bans.

The upward trend in interstate policy variation is not inevitable, however. In 2017, the federal government came under unified Republican control. The Trump administration has signaled a desire to act against state and local immigration and marijuana policies. Recent decades saw the buildup of considerable interstate policy variation, but an aggressive federal government may move the center of policymaking in American federalism back to the national government. Further research should investigate interbranch conflict in the polarized era.

\section{Notes}

1 Newell 2011.

2 Allen 1949; Sharkansky 1968; Teaford 2002, 2.

3 Peterson 1981; Kousser 2005.

4 E.g., Kousser 2002; Hertel-Fernandez and Skocpol 2016; Hertel-Fernandez 2016.

5 Caughey and Warshaw 2016, 7.

6 Caughey, Xu, and Warshaw 2016, 1.

7 Anzia 2011; Rogers 2016.

8 E.g., Bishop 2009; Abramowitz 2010. 
9 Hertel-Fernandez 2014.

10 E.g., Fehrman 2016.

11 Recent research on temporal dynamics in state policy summarizes policy with unidimensional left-right ideal points (e.g., Caughey and Warshaw 2016), which are difficult to interpret in substantive policy terms.

12 Policy variation between states can occur for partisan or nonpartisan reasons. It represents durable differences in laws, regulations, and policies between states. Policy polarization represents the polarization of parties in government (i.e., the effect on policy of being a blue or red state in a given year). If a state's party control changes frequently, policy polarization can generate large pendulum or thermostatic swings in policy outcomes without increasing policy variation.

13 Elazar 1990.

14 Winston 2002, 106.

15 Brace and Jewett 1995, 655. Researchers have correspondingly used the state level as a way to increase their $\mathrm{N}$ to 50 in cross-sectional studies of the roles of public opinion, interest groups, descriptive representation, or institutional rules and legislative organization. There are certainly advantages to increasing one's $\mathrm{N}$ of institutional venues to 50 , but analysis of a cross-sectional "snapshot" is unlikely to detect systemic changes that occur over time; Pierson and Skocpol 2002; Pierson 2004.

16 E.g., Mettler 1998; Allen, Pettus, and Haider-Markel 2004.

17 Kincaid 1990, 144. See also Posner 2007; Zimmerman 2009. In addition, a few conservative commentators counter the minimalist view, arguing, for instance, that liberal state governments like that of the "failed state of California" are too active in attempts "to regulate the internet, to tax corporations on profits earned in foreign jurisdictions, and to impose sales tax collection obligations on internet sellers domiciled elsewhere"; Greve 2011, 6.

18 Riker 1975, 143.

19 Peterson 1981; Oates 1999.

20 However, some research challenges the prediction of a "race to the bottom" in the states; Volden 2002; Konisky 2007.

21 Researchers highlight the inability to devalue a currency as a major barrier to fiscal policy in lower income Eurozone countries; e.g., Krugman 2013.

22 Kousser 2005.

23 Shor and McCarty 2011.

24 This is true at least to the extent this polarization is ideological, as well as to the extent that non-ideological partisan brinksmanship incentivizes ideologically distinct policy agendas; Lee 2009. Indeed, there is evidence that the ideological positions of state governments affect their responses to economic forces such as exposure to global trade; Krueger and Xu 2015.

25 Caughey and Warshaw 2016; Caughey, Xu, and Warshaw 2017, 1356.

26 For other examples of minimal effects of party control see Garand 1988; Erikson, Wright, and McIver 1993; Jacobs and Carmichael 2002; Konisky 2007.

27 E.g., Abramowitz and Saunders 2008; Abramowitz 2010.

28 Bishop 2009. See also Sussell and Thomson 2015.

29 Anzia 2011; Hopkins 2017.

30 Arnold 1992.

31 Rogers 2016.

32 E.g, Schattschneider 1960; Riker 1964; McConnell 1966, 139-155.

33 Schattschneider 1960, 63.

34 Converse 1964.

35 Bawn et al. 2012; Skocpol and Hertel-Fernandez 2016.

36 Hertel-Fernandez 2014; Hertel-Fernandez, Skocpol and Lynch 2016.

37 Baumgartner and Jones 2010.

38 Kousser 2005.

39 Hall and Deardorff 2006.

40 E.g., Dahl 1960.

41 E.g., Mills 1956; Lowi 1967.

42 Krimmel 2017.

43 E.g., Riker 1964; Pierson 1995.

44 Rabe 2004.

45 Meyerson 2014.

46 Lax and Phillips 2009.

47 Skocpol and Hertel-Fernandez 2016.

48 Binder 2003.

49 An expansion of national policy from the New Deal through the early 1970s "centralized" governance and standardized the welfare state and civil rights law across the states; Melnick 1996; Mettler 1998; Campbell 2014. Although New Deal programs allowed states to exclude many black Americans from benefits (Weir 2005; Katznelson 2013), landmark policies like the Social Security Act of 1935 and the Civil Rights Act of 1964 decreased interstate policy variation by establishing or raising legal and economic baselines. This process of centralization continued in the welfare and regulatory buildup of the 1960s and 1970s. Landmark federal policies that decreased state variation during this era include the Social Security Amendments of 1965 and 1972, the Gun Control Act of 1968, the National Environmental Policy Act of 1969, and the Clean Air Act of 1970.

50 McCarty, Poole, and Rosenthal 2006.

51 Binder 1999. 
52 Hacker 2004.

53 As shown in the online appendix, figure 8, the federal government has been more likely to be under divided party control than state governments in recent decades. Between 1970 and 2014, the U.S. House, Senate, and presidency have only been under unified party control about $27 \%$ of the time (12 of 45 years), whereas the average state has been under unified control about $50 \%$ of the time. Regardless of the cause of this difference, we would expect relatively less gridlock in the states as polarization increases, and, in turn, a relative growth in the role of state governments as major policymakers.

54 E.g., Mooney 2000; Feeley and Rubin 2009; Chatfield and Rocco 2014.

55 Chatfield and Rocco 2014, 4.

56 E.g., Soss et al. 2001; Grogan and Rigby 2008; Kelly and Witko 2012.

57 Whittington 2001; Waltenburg and Swinford 1999, 2.

58 Baum 2015. In addition, various measures of fiscal activity show an expanding role of state government since the 1970s. I plot total state government spending, employment, and average state tax rates as a percentage of federal spending, employment, and tax rates in the online appendix, figure 7.

59 I start in 1970 for two reasons. First, no modern state law is substantively comparable to those of the Jim Crow regime, which entailed mass disenfranchisement of black Americans and a de jure racial caste system. Second, although Caughey and Warshaw 2016 employ data going back to 1937 , their model's parameters for early state policies may be substantively invalid, and state ideal point estimates also have high degrees of uncertainty in the pre-1970 period; see Grumbach 2017.

60 Jordan and Grossmann 2016; Caughey and Warshaw 2016; and Boehmke and Skinner 2012.

61 Caughey and Warshaw 2016, 4-5 and the online appendix.

62 Prominent sources of policy data are Anzia and Moe 2017, the Guttmacher Institute, Barber 2016, and the National Council of State Legislators.

63 E.g., Yates and Fording 2005.

64 For instance, aside from a few drug-related policies (e.g., medical marijuana laws), the Caughey and Warshaw 2016 dataset only contains data on four criminal justice policies: death penalty repeal, the establishment of probation (only for the 1936-1939 period), animal cruelty as a felony, and age span provisions for statutory rape cases (i.e., the decriminalization of sex between consenting teenagers of similar ages). These policies are generally orthogonal to the rise of mass incarceration.

65 For a review see Travis, Western, and Redburn 2014, ch. 3.
66 Klarner 2013.

67 Smith 1997.

68 Binder 1999.

69 E.g., Caughey, Xu, and Warshaw 2016, table 3.

70 Setting this threshold between 1999 and 2000 strikes a balance between periods that are long enough (precision) and highlighting the potentially precipitous increase in policy polarization in the most recent years of hyper-polarization; Mann and Ornstein 2013. In the online appendix I provide additional estimates using the 1970-1991 and 1992-2014 periods following Caughey, $\mathrm{Xu}$, and Warshaw 2016.

71 Erikson, Wright, and McIver 1993; Caughey and Warshaw 2016.

72 Erikson, MacKuen, and Stimson 2002, ch. 9.

73 The Substantive scales, which do not use data from earlier years to smooth ideal points over time like the Bayesian IRT measures, show slightly larger increases in range and standard deviation over time (starting from slightly lower in the 1970s and ending slightly higher in the 2010s).

74 As is described in detail in Grumbach 2018, the three measures that employ my full policy dataset show larger party effects after 2000.

75 Broockman 2016.

76 E.g., Clinton, Jackman, and Rivers 2004.

77 Grumbach 2018,. The discrimination parameter for occupational licensing for beauticians is liberal but the parameter for licensing for nurses is conservative.

78 Caughey and Warshaw 2016, 7.

79 E.g., Norrander and Wilcox 1999; Hero and Preuhs 2007.

80 See also Erikson, MacKuen, and Stimson 2002, ch. 9.

81 One might argue, for example, that voter ID laws are more substantively and normatively consequential than motor voter laws, and should thus be weighted more heavily in calculating the issue area indices.

82 Rawls 1971; Foner 1984; Weir 2005; Wang 2005; Brinkley 2011.

83 DuBois 1935; Foner 1988; Kessler-Harris 2001; Shelby 2005; Kollman and Waites 2009.

84 Simon 2007.

85 Himmelstein 1992; Brinkley 1994; Harvey 2007.

86 Poole and Rosenthal 1997.

87 E.g., Haidt 2012.

88 E.g., Karol 2009; Bawn et al. 2012.

89 Within an issue area, a policy can be on the "left" or "right," but these terms are simply shorthand for the concepts described in table 2.

90 E.g., Schickler 2013.

91 Of the 135 policies shown in table 1 , I exclude the 15 in the Other category because they (a) have unclear issue-specific ideological content (e.g., animal cruelty 
felony), (b) are socioeconomically inconsequential (e.g., beer keg registration), or (c) are insufficiently varied or numerous to create an issue area (e.g., state lotteries).

92 The figure of $\$ 268$ per month is about $16 \%$ of the Federal Poverty Level for a family of three.

93 The 1996 welfare reform made legal immigrants ineligible for federal benefits for the first five years of residency; some states then moved to cover these new immigrants in their Medicaid, TANF, and SCHIP programs using only state funding; Hero and Preuhs 2007.

94 Medoff and Dennis 2011,955.

95 I follow the dynamic panel models of Caughey, $\mathrm{Xu}$, Warshaw 2016, who add lagged dependent variables for year $\mathrm{t}-1$ and $\mathrm{t}-2$ to traditional two-way fixed effects models to improve fit. Alternative specifications are provided in the online appendix.

96 Dickman et al. 2014.

97 However, I do find a modest increase in polarization in $\mathrm{K}-12$ spending per pupil (but not higher education spending), with Democratic governments spending more than Republican governments after 2000.

98 E.g., DeBray 2006; Hursh 2007; Weaver 2007; Alexander 2012; Wolbrecht and Hartney 2014.

99 Weaver 2007; Lacey 2008; Wacquant 2009; Alexander 2012.

100 Western 2006; Manza and Uggen 2008; Weaver and Lerman 2010.

101 Miller 2008, 2016; Lacey and Soskice 2015.

102 Weaver 2007, 261.

103 Alexander 2012, 55-56.

104 Though the states' execution of 1445 individuals since 1976 is of great social consequence, it is less related to mass incarceration than the other policies because in all likelihood these individuals would have been given a life sentence had the death penalty not been in effect. Moreover, the death penalty is unique because Texas is responsible for nearly one-third (542) of the executions in the U.S. since the death penalty was ruled constitutional in 1976.

105 Yates and Fording 2005.

106 Data on incarcerated populations is from the Bureau of Justice Statistics (ICPSR 36281). Yearly state population estimates by race are from linear interpolation of decennial Census numbers; Weden et al. 2015.

107 This is the 2014 estimate from the Bureau of Justice Statistics, and it includes people on parole or probation.

108 Price and Riccucci 2005 test the cross-sectional relationship between partisan and ideological variables and private incarceration for the year 1990 . To my understanding, this is the first test of this relationship across time.
109 Shapiro 2011.

110 The dependent variable is the average freshman graduation rate, the percentage of an entering freshman class that graduates high school in four years. Data is from the National Center for Education Statistics. Estimates of partisan differences in graduation rates are reduced further with the inclusion of state poverty rate in the time-series regressions.

111 Melnick 1996; Mettler 1998; Hacker and Pierson 2010; Campbell 2014.

112 Soss et al. 2001.

113 Beland, Rocco, and Waddan 2016.

\section{Supplementary Materials}

The below supplementary materials are available at https://doi.org/10.1017/S153759271700425X:

- Polarized Federalism and the Size of Government

- Party Control of Government

- Policy Productivity

- Party Control and Criminal Justice Outcomes

- Party Control and Environmental Outcomes

- Party Control and Education Outcomes

- Additional Regression Specifications

- Alternative Temporal Breakpoints

- Policy Data

\section{References}

Abramowitz, Alan I. 2010. The Disappearing Center: Engaged Citizens, Polarization, and American democracy. New Haven, CT: Yale University Press.

Abramowitz, Alan I. and Saunders Kyle L. 2008. "Is Polarization a Myth?” Journal of Politics 70(2): 542-55. Alexander, Michelle. 2012. The New Jim Crow: Mass Incarceration in the Age of Colorblindness. New York: New Press.

Allen, Mahalley D., Carrie Pettus, and Donald P. HaiderMarkel. 2004. "Making the National Local: Specifying the Conditions for National Government Influence on State Policymaking." State Politics \& Policy Quarterly 4(3): 318-44.

Allen, Robert Sharon. 1949. Our Sovereign State. New York: Vanguard Press.

Anzia, Sarah F. 2011. "Election Timing and the Electoral Influence of Interest Groups." Journal of Politics 73(2): 412-27.

Anzia, Sarah F. and Terry M. Moe. 2017. "Do Politicians Use Policy to Make Politics? The Case of Public-Sector Labor Laws." American Political Science Review 110(4): 763-77.

Arnold, Douglas R. 1992. The Logic of Congressional action. New Have, CT: Yale University Press.

Barber, Michael. 2016. "Ideological Donors, Contribution Limits, and the Polarization of State Legislatures." Journal of Politics 78(1): 296-310. 
Baum, Lawrence. 2015. The Supreme Court. Washington, DC: CQ Press.

Baumgartner, Frank R. and Bryan D. Jones. 2010. Agendas and Instability in American Politics. Chicago: University of Chicago Press.

Bawn, Kathleen, Martin Cohen, David Karol, Seth Masket, Hans Noel and John Zaller. 2012. "A Theory of Political Parties: Groups, Policy Demands and Nominations in American Politics." Perspectives on Politics 10(3): 571-97.

Beland, Daniel, Philip Rocco, and Alex Waddan. 2016. Obamacare Wars. Lawrence: University Press of Kansas.

Binder, Sarah A. 1999. "The Dynamics of Legislative Gridlock, 1947-96." American Political Science Review 93(3): 519-33.

2003. Stalemate: Causes and Consequences of Legislative Gridlock. Washington, DC: Brookings Institution Press.

Bishop, Bill. 2009. The Big Sort: Why the Clustering of Like-Minded America Is Tearing Us Apart. New York: Houghton Mifflin Harcourt.

Boehmke, Frederick J. and Paul Skinner. 2012. "State Policy Innovativeness Revisited." State Politics \& Policy Quarterly 12(3): 303-29.

Brace, Paul and Aubrey Jewett. 1995. "The State of State Politics Research.” Political Research Quarterly 48(3): 643-81.

Brinkley, Alan. 1994. "The Problem of American Conservatism." American Historical Review 99(2): 409-29.

- 2011. The End of Reform: New Deal Liberalism in Recession and War. New York: Vintage.

Broockman, David E. 2016. "Approaches to Studying Policy Representation." Legislative Studies Quarterly 41(1): 181-215.

Campbell, Ballard C. 2014. The Growth of American Government: Governance from the Cleveland Era to the Present. Bloomington,: Indiana University Press.

Caughey, Devin and Christopher Warshaw. 2016. "The Dynamics of State Policy Liberalism, 1936-2012." American Journal of Political Science 60(4): 899-913.

Caughey, Devin, Yiqing Xu, and Christopher Warshaw. 2017. "Incremental Democracy: The Policy Effects of Partisan Control of State Government." Journal of Politics 79(4): 1342-58.

Chatfield, Sara and Philip Rocco. 2014. "Is Federalism a Political Safety Valve? Evidence from Congressional Decision Making, 1960-005." Publius: The Journal of Federalism 44(1): 1-23.

Clinton, Joshua, Simon Jackman, and Douglas Rivers. 2004. "The Statistical Analysis of Roll Call Data." American Political Science Review 98(2): 355-70.

Converse, Philip. 1964. "The Nature of Belief Systems in Mass Publics". In Ideology and Discontent, ed. David Apter. New York: Free Press.
Dahl, Robert A. 1960. Who Governs? Democracy and Power in an American City. New Haven, CT: Yale University Press.

DeBray, Elizabeth H. 2006. Politics, Ideology, and Education. New York: Teachers College Press.

Dickman, Sam, David Himmelstein, Danny McCormick and Steffie Woolhandler. 2014. "Opting Out of Medicaid Expansion: The Health and Financial Impacts." Health Affairs, January 30. Available at http://healthaffairs.org/blog/2014/01/30/opting-out-ofmedicaid-expansion-the-health-and-financial-impacts/.

DuBois, W. E. B. 1935. Black Reconstruction in America: An Essay Toward a History of the Part Which Black Folk Played in the Attempt to Reconstruct Democracy in America, 1860-1880. New York: Harcourt Brace.

Elazar, Daniel J. 1990. "Opening the Third Century of American Federalism: Issues and Prospects." Annals of the American Academy of Political and Social Science 509(1): 11-21.

Erikson, Robert S., Gerald C. Wright, and John P. McIver. 1993. Statehouse Democracy: Public Opinion and Policy in the American States. New York: Cambridge University Press.

Erikson, Robert S., Michael B. MacKuen, and James A. Stimson. 2002. The Macro Polity. New York: Cambridge University Press.

Feeley, Malcolm and Edward Rubin. 2009. Federalism: Political Identity and Tragic Compromise. Ann Arbor: University of Michigan Press.

Fehrman, Craig. 2016. "All Politics Is National." Five ThirtyEight November 7. Available at https:// fivethirtyeight.com/features/all-politics-is-national/.

Foner, Eric. 1984. "Why Is There No Socialism in the United States?" History Workshop 17(Spring): 57-80.

- 1988. Reconstruction: America's Unfinished Revolution, 1863-1877. New York: Harper \& Row.

Garand, James C. 1988. "Explaining Government Growth in the U.S. States." American Political Science Review 82(3): 837-49.

Granger, Clive W. J. and Paul Newbold. 1974. "Spurious Regressions in Econometrics." Journal of Econometrics 2(2): 111-20.

Greve, Michael S. 2011. "The State of Our Federalism." American Enterprise Institute. Available at https:// www.aei.org/wp-content/uploads/2011/10/State-ofFederalism-Greve.pdf.

Grogan, Colleen M. and Elizabeth Rigby. 2008. "Federalism, Partisan Politics, and Shifting Support for State Flexibility: The Case of the U.S. State Children's Health Insurance Program." Publius: The Journal of Federalism 39: 1-23.

Grossmann, Matt. 2014. Artists of the Possible: Governing Networks and American Policy Change since 1945. New York: Oxford University Press.

Grumbach, Jacob M. 2018. "How Should We Estimate State Policy Outcomes?" Working Paper. Available at 
https://www.dropbox.com/s/zu2fc67x7ioayaf/ METHODS\%20State\%20Policy\%20Resurgence $\%$ 2017.5.25.pdf?dl $=0$.

Guttmacher Institute. 2003-2014. "State Policies on Later-Term Abortions." State Policies in Brief.

Hacker, Jacob S. 2004. "Privatizing Risk without Privatizing the Welfare State: The Hidden Politics of Social Policy Retrenchment in the United States." American Political Science Review 98(2): 243-60.

Hacker, Jacob S. and Paul Pierson. 2010. "WinnerTake-All Politics: Public Policy, Political Organization, and the Precipitous Rise of Top Incomes in the United States." Politics \& Society 38(2): 152-204.

Haidt, Jonathan. 2012. The Righteous Mind: Why Good People Are Divided by Politics and Religion. New York: Vintage.

Hall, Richard L. and Alan V. Deardorff. 2006. "Lobbying as Legislative Subsidy." American Political Science Review 100(1): 69-84.

Harvey, David. 2007. A Brief History of Neoliberalism. New York: Oxford University Press.

Hero, Rodney E. and Robert R. Preuhs. 2007. "Immigration and the Evolving American Welfare State: Examining Policies in the U.S. States." American Journal of Political Science 51(3): 498-517.

Hertel-Fernandez, Alexander. 2014. "Who Passes

Business's Model Bills? Policy Capacity and Corporate Influence in U.S. State Politics." Perspectives on Politics 12(3): 582-602.

. 2016. "Explaining Liberal Policy Woes in the States: The Role of Donors." PS: Political Science \& Politics 49(3): 461-465.

Hertel-Fernandez, Alexander and Theda Skocpol. 2016. "How the Right Trounced Liberals in the States." Democracy: A Journal of Ideas Winter (39). Available at https://democracyjournal.org/magazine/39/how-theright-trounced-liberals-in-the-states/.

Hertel-Fernandez, Alexander, Theda Skocpol, and Daniel Lynch. 2016. "Business Associations, Conservative Networks, and the Ongoing Republican War over Medicaid Expansion." Journal of Health Politics, Policy and Law 41(2): 239-86.

Himmelstein, Jerome L. 1992. To the Right: The Transformation of American Conservatism. Berkeley: University of California Press.

Hopkins, Daniel J. 2018. The Increasingly United States: How And Why American Political Behavior Nationalized. Chicago: University of Chicago Press.

Hursh, David. 2007. "Assessing No Child Left Behind and the Rise of Neoliberal Education Policies." American Educational Research Journal 44(3): 493-518.

Jacobs, David and Jason T. Carmichael. 2002. "The Political Sociology of the Death Penalty: A Pooled Time-Series Analysis." American Sociological Review 67(1): 109-31.
Jordan, Marty P. and Matt Grossmann. 2016. "The Correlates of State Policy Project v.1.5.” Available at http://ippsr.msu.edu/public-policy/correlates-statepolicy.

Karol, David. 2009. Party Position Change in American Politics: Coalition Management. New York: Cambridge University Press.

Katznelson, Ira. 2013. Fear Itself: The New Deal and the Origins of Our Time. New York: W.W. Norton \& Company.

Kelly, Nathan J. and Christopher Witko. 2012. "Federalism and American Inequality." Journal of Politics 74(2): 414-26.

Kessler-Harris, Alice. 2001. In Pursuit of Equity: Women, Men, and the Quest for Economic Citizenship in 20th-Century America. New York: Oxford University Press.

Kincaid, John. 1990. "From Cooperative to Coercive Federalism." Annals of the American Academy of Political and Social Science 509: 139-52.

Klarner, Carl. 2013. "State Partisan Balance Data, 1937-2011." Harvard Dataverse. Available at http:// hdl.handle.net/1902.1/20403.

Kollman, Kelly. and Matthew Waites. 2009. "The Global Politics of Lesbian, Gay, Bisexual and Transgender Human Rights: An Introduction." Contemporary Politics 15(1): 1-17.

Konisky, David M. 2007. "Regulatory Competition and Environmental Enforcement: Is There a Race to the Bottom?" American Journal of Political Science 51(4): 853-72.

Kousser, Thad. 2002. "The Politics of Discretionary Medicaid Spending, 1980-1993." Journal of Health Politics, Policy and Law 27(4): 639-72.

- 2005. Term Limits and the Dismantling of State Legislative Professionalism. New York: Cambridge University Press.

Krimmel, Katherine. 2017. "The Efficiencies and Pathologies of Special Interest Partisanship." Studies in American Political Development, 31(2): 149-69.

Krueger, Brian S. and Ping Xu. 2015. "Trade Exposure and the Polarization of Government Spending in the American States." American Politics Research 43(5): 793-820.

Krugman, Paul. 2013. "Revenge of the Optimum Currency Area." NBER Macroeconomics Annual 27(1): 439-48.

Lacey, Nicola. 2008. The Prisoners' Dilemma: Political Economy and Punishment in Contemporary Democracies. Cambridge: Cambridge University Press.

Lacey, Nicola. and David Soskice. 2015. "Crime, Punishment and Segregation in the United States: The Paradox of Local Democracy." Punishment \& Society 17(4): 454-81. 
Lax, Jeffrey R. and Justin H. Phillips. 2009. "Gay Rights in the States: Public Opinion and Policy Responsiveness.” American Political Science Review 103(3): 367-86.

Lee, Frances E. 2009. Beyond Ideology: Politics, Principles, and Partisanship in the U.S. Senate. Chicago: University of Chicago Press.

Lowi, Theodore. 1967. "The Public Philosophy: InterestGroup Liberalism." American Political Science Review 61(1): 5-24.

Mann, Thomas E. and Norman J Ornstein. 2013. It's Even Worse Than It Looks: How the American Constitutional System Collided with the New Politics of Extremism. New York: Basic Books.

Manza, Jeff and Christopher Uggen. 2008. Locked Out: Felon Disenfranchisement and American Democracy. Oxford: Oxford University Press.

McCarty, Nolan, Keith T Poole, and Howard Rosenthal. 2006. Polarized America: The Dance of Ideology and Unequal Riches. Vol. 5. Cambridge, MA: MIT Press.

McConnell, Grant. 1966. Private Power \& American Democracy. New York: Knopf.

Medoff, Marshall H. and Christopher Dennis. 2011. "TRAP Abortion Laws and Partisan Political Party Control of State Government." American Journal of Economics and Sociology 70(4): 951-73.

Melnick, R. Shep. 1996. "Federalism and the New Rights." Yale Law \& Policy Review 14(2): 325-54.

Mettler, Suzanne. 1998. Dividing Citizens: Gender and Federalism in New Deal Public Policy. Ithica, NY: Cornell University Press.

Meyerson, Harold. 2014. "The Seeds of a New Labor Movement." The American Prospect. Available at http://prospect.org/article/labor-crossroads-seeds-newmovement.

Miller, Lisa L. 2008. The Perils of Federalism: Race, Poverty, and the Politics of Crime Control. Oxford: Oxford University Press.

2016. The Myth of Mob Rule: Violent Crime and Democratic Politics. Oxford: Oxford University Press.

Mills, Charles. 1956. The Power Elite. New York: Oxford University Press.

Mooney, Christopher Z. 2000. "The Decline of Federalism and the Rise of Morality-Policy Conflict in the United States." Publius: The Journal of Federalism 30(1): 171-88.

National Center for Education Statistics. 2015. "Digest of Education Statistics." Available at https://nces.ed.gov/ programs/digest/d15/.

National Council of State Legislators. 2017. "Drug Testing for Welfare Recipients and Public Assistance." Available at http://www.ncsl.org/research/humanservices/drug-testing-and-public-assistance.aspx.

Newell, Jim. 2011. “Gov. Scott Walker's Amazing Prank Call with 'David Koch'.' Gawker, February 23.
Available at http://gawker.com/5768410/gov-scottwalkers-amazing-prank-call-with-david-koch.

Norrander, Barbara and Clyde Wilcox. 1999. "Public Opinion and Policymaking in the States: The Case of Post-Roe Abortion Policy." Policy Studies Journal 27(4): 707-22.

Oates, Wallace E. 1999. "An Essay on Fiscal Federalism.” Journal of Economic Literature 37(3) 1120-49.

Peterson, Paul E. 1981. City Limits. Chicago: University of Chicago Press.

Pierson, Paul. 1995. "Fragmented Welfare States: Federal Institutions and the Development of Social Policy." Governance 8(4): 449-78.

- 2004. Politics in Time: History, Institutions, and Social Analysis. Princeton, NJ: Princeton University Press.

Pierson, Paul and Theda Skocpol. 2002. "Historical Institutionalism in Contemporary Political Science." Political Science: The State of the Discipline 3:693-721.

Poole, Keith T. and Howard Rosenthal. 1997. Congress: A Political-Economic History of Roll Call Voting. New York: Oxford University Press.

Posner, Paul. 2007. "The Politics of Coercive Federalism in the Bush Era." Publius: The Journal of Federalism 37(3): 390-412.

Price, Byron E. and Norma M. Riccucci. 2005. "Exploring the Determinants of Decisions to Privatize State Prisons." American Review of Public Administration 35(3): 223-35.

Rabe, Barry G. 2004. Statehouse and Greenhouse: The Emerging Politics of American Climate Change Policy. Washington, DC: Brookings Institution Press.

Rawls, John. 1971. A Theory of Justice. Cambridge, MA: Harvard University Press.

Riker, William H. 1964. Federalism: Origin, Operation, Significance. Boston: Little, Brown.

. 1975. "Federalism". In Handbook of Political Science: Governmental Institutions and Processes, ed. Fred I. Greenstein and Nelson W. Polsby. Boston: Addison-Wesley.

Rogers, Steven. 2016. "National Forces in State Legislative Elections." Annals of the American Academy of Political and Social Science 667(1): 207-25.

Schattschneider, E. E. 1960. The Semi-Sovereign People. New York: Holt, Rinehart and Winston.

Schickler, Eric. 2013. "New Deal Liberalism and Racial Liberalism in the Mass Public, 1937-1968."

Perspectives on Politics 11(1): 75-98.

Shapiro, David. 2011. "Banking on Bondage: Private Prisons and Mass Incarceration.” American Civil Liberties Union. Available at https://www.aclu.org/ banking-bondage-private-prisons-and-mass-incarceration.

Sharkansky, Ira. 1968. "Economic Development, Regionalism and State Political Systems." Midwest Journal of Political Science 12(1): 41-61. 
Shelby, Tommie. 2005. We Who Are Dark: The Philosophical Foundations of Black Solidarity.

Cambridge, MA: Harvard University Press.

Shor, Boris and Nolan McCarty. 2011. "The Ideological Mapping of American Legislatures." American Political Science Review 105(3): 530-51.

Simon, Jonathan. 2007. Governing Through Crime: How the War on Crime Transformed American Democracy and Created a Culture of Fear. New York: Oxford University Press.

Skocpol, Theda and Alexander Hertel-Fernandez. 2016. "The Koch Network and Republican Party Extremism." Perspectives on Politics 14(3): 681-99.

Smith, Mark A. 1997. "The Nature of Party Governance: Connecting Conceptualization and Measurement." American Journal of Political Science 41(3): 1042-56.

Soss, Joe, Sanford F. Schram, Thomas P. Vartanian, and Erin O'Brien. 2001. "Setting the Terms of Relief: Explaining State Policy Choices in the Devolution Revolution." American Journal of Political Science 45(2): 378-95.

Sussell, Jesse and James A. Thomson. 2015. Are Changing Constituencies Driving Rising Polarization in the US House of Representatives? Santa Monica, CA: Rand Corporation.

Teaford, Jon C. 2002. The Rise of the States: Evolution of American State Government. Vol. 120 Baltimore: Johns Hopkins University Press.

Travis, Jeremy, Bruce Western, and Steve Redburn. 2014. The Growth of Incarceration in the United States: Exploring Causes and Consequences. Washington, DC: National Academies Press.

Volden, Craig. 2002. "The Politics of Competitive Federalism: A Race to the Bottom in Welfare Benefits?" American Journal of Political Science 46(2): 352-63.

Wacquant, Loic. 2009. Punishing the Poor: The Neoliberal Government of Social Insecurity. Durham, NC: Duke University Press.

Waltenburg, E. N. and B. Swinford. 1999. Litigating Federalism: The States before the U.S. Supreme Court. New York: Greenwood Publishing Group.
Wang, Jessica. 2005. "Imagining the Administrative State: Legal Pragmatism, Securities Regulation, and New Deal Liberalism." Journal of Policy History 17(3): 257-93.

Weaver, Vesla M. 2007. "Frontlash: Race and the Development of Punitive Crime Policy." Studies in American Political Development 21(2): 230-65.

Weaver, Vesla M. and Amy E. Lerman. 2010. "Political Consequences of the Carceral State." American Political Science Review 104(4): 817-33.

Weden, Margaret M., Christine E. Peterson, Jeremy N. Miles, and Regina A. Shih. 2015. "Evaluating Linearly Interpolated Intercensal Estimates of Demographic and Socioeconomic Characteristics of U.S. Counties and Census Tracts 2001-2009." Population Research and Policy Review 34(4): 541-59.

Weir, Margaret. 2005. "States, Race, and the Decline of New Deal Liberalism." Studies in American Political Development 19(2): 157-72.

Western, Bruce. 2006. Punishment and Inequality in America. New York: Russell Sage Foundation.

Whittington, Keith E. 2001. "Taking What They Give Us: Explaining the Court's Federalism Offensive." Duke Law Journal 51(1): 477-520.

Winston, Pamela. 2002. Welfare Policymaking in the States: The Devil in Devolution. Washington, DC: Georgetown University Press.

Wolbrecht, Christina and Michael Tm Hartney. 2014. "Ideas about Interests: Explaining the Changing Partisan Politics of Education." Perspectives on Politics 12(3): 603-30.

Yates, Jeff and Richard Fording. 2005. "Politics and State Punitiveness in Black and White." Journal of Politics 67(4): 1099-121.

Zimmerman, Joseph F. 2009. Contemporary American Federalism: The Growth of National Power. Albany: SUNY Press. 